American Research Journal of English and Literature

ISSN(Online): 2378-9026

Volume 5, Issue 1, 2019, 1-2 Pages

DOI: 10.21694/2378-9026.19004

AMERICAN RESEARCH JOURNALS

An Academic Publishing \#ause

Review of Enid Blyton's House at the Corner

\title{
House at the Corner: A Call for Family Solidarity and Character Integrity
}

\author{
Dr. Omar Osman Jabak \\ Department of Arts and Education, Community College, King Saud University, Saudi Arabia. \\ ojabak@ksu.edu.sa
}

I have recently had the opportunity to read Enid Mary Blyton's House at the Corner. The novel revolves around the importance of unity in the face of difficulties as the individual alone cannot often overcome hardships and need the help and support of his/her family. It also shows that selfish, careless people will experience hardships and mishaps that will compel them to change their attitude and behavior, or they will get into harder trouble whose repercussions may be painfully costly. The novel also emphasizes the necessity of character integrity.

As the novelist took me on a trip to this house, I got introduced to the people dwelling there. I read about Aunt Grace arriving at the house she was brought up in; the house which was known as the house at the corner because passengers could see it from the windows of the train heading for the station at the corner opposite the hills. She appeared with her baggage and her parrot in a cage with its sunflower seeds. Aunt Grace helped keep the house when she stood by her nephew to become the famous surgeon, John Farrell, who preserved the house and did not sell it.

Blyton then introduces us to John Farrell's family with so much detail about each of his family members. This assiduous attention to minute details and lengthy descriptions may have a deterrent effect on some readers. The Farrells consist of the father, John, the mother, Lucy, the eldest daughter, Pamela who is proud of her beauty and intelligence, but selfish, the eldest son, Tony who is care-free and full of pranks, the second eldest daughter, Lizzie who is good-hearted, with average (plain) beauty and grades at school, but she is very good at writing especially children's stories although her family neglects her and does not encourage her, the ten-year twins, Delia and David along with their loyal and wise friend Michael who are so good at gardening and looking after animals and birds that they know almost everything about them and finally their Australian house-keeper, Greta who considers herself, and everyone does, a family member except Pamela who treats her as a maid or servant.

Aunt Grace has a discerning look and contributes greatly to changing the behavior and attitude of almost all the characters of the novel. She encourages Lizzie who wishes to be called "Elizabeth Farrell", to become a successful writer by contacting newspapers where she can publish what she writes and gets paid for that without the knowledge of any family member, save Aunt Grace.

Aunt Grace also helps the twins by making everyone regard them as responsible adults with some distinguished skills. She helps Pam or Pamela to stop being selfish and learn some housework. She helps Tony to be responsible, and Lucy, the mother, to change the way she uses to encourage Pam and Tony to be selfish and irresponsible and the way she would also treat the twins as irresponsible babies. In fact, Aunt Grace helps the whole family to preserve the house and be united after the terrible car accident which Doctor John Farrell has and which leaves him with an injury in the right hand, and as a result he stops working for about a year.

www.arjonline.org

Page 1 
On the day of the accident, Pamela acts very rudely and asks her father not to see her playing a princess's role in a play because he has previously asked her to care for the scholarship test. Later on and after the accident, Pam starts blaming herself as she really lost the scholarship. Consequently, her arrogance is wounded, and she starts behaving more humbly by sharing the house work with her sister after her rude treatment has caused Greta, the house-keeper, to leave the house and after Pam sees that everyone in the house is offering to help and share the household expenses after her father's accident. Moreover, Tony gets expelled from school because of one of his irresponsible pranks that has caused one of his fellow students a severe injury. As a result, all Tony's friends, who have been encouraging him to play pranks, turn their back on him and abandon him.

Aunt Grace takes advantage of the Farrells' ordeal to change Pamela and Lucy. Later on, when she, Aunt Grace, realizes Pamela has really changed, she offers her money to send her to college and keeps the house at the corner united and happy.

The novel revolves around the importance of the unity of the family in the face of ordeals as the individual members alone cannot stand ordeals, as the saying goes "united we stand, divided we fall". It also shows that selfish, irresponsible people will receive blows that will force them to change, or else they will receive harder blows whose consequences may not be favorable at all. The novel emphasizes the organic relationship between one's appearance and inner soul and that one's outside appearance reflects one's inner self. The quotes that attract me most are "Pray to God- but row for the shore" (p.210) and "Such little things - and what big things they became when it was too late." (p.166).

The novel ends with things coming back to normal in the house at the corner; the father gets out of the hospital, Pamela goes to college, Tony becomes responsible and serious about his study after the injured student's father interferes to bring him back to school, Lizzie takes off her glasses and bracelet after she gets better to become a wonderful, confident girl, the twins go to the same school and will not part and everyone knows their talents and sense of responsibility, and finally Greta comes back to the house to help. On that night everyone goes to bed under one roof; the roof of the house at the corner, as one united family!

In conclusion, the novel, 271 pages long, is worth reading as a family book suitable for all family members despite some repetitions here and there, especially in the description of the characters, which some readers, like myself, may find somehow boring and unnecessary. The novelist succeeds in depicting the minute details of a typical family's life with its bitter and sweet experiences. Perhaps, the novelist wants to draw the attention of parents, in general, and the younger generation, in particular, to the necessity of preserving the structure of a family as it is the corner stone of society. Family members are the only ones who care for each other without excepting any personal gains in return and without intending to harm their family members. The novel also stresses the importance of character integrity which leads to the individual's ultimate success and happiness.

\section{REFERENCES}

1. Blyton, Enid. (1947). House at the Corner. Luttlerworth Press.

Citation: Dr. Omar Osman Jabak, "Review of Enid Blyton's House at the Corner House at the Corner: A Call for Family Solidarity and Character Integrity" American Research Journal of English and Literature, vol 5, no. 1, 2019, pp. 1-2.

Copyright (c) 2019 Dr. Omar Osman Jabak, This is an open access article distributed under the Creative Commons Attribution License, which permits unrestricted use, distribution, and reproduction in any medium, provided the original work is properly cited.

American Research Journal of English and Literature

Page 2 